Article

\title{
An Effective Surrogate Tracer Technique for S. aureus Bioaerosols in a Mechanically Ventilated Hospital Room Replica Using Dilute Aqueous Lithium Chloride
}

\author{
Marco-Felipe King ${ }^{1, *}$ (D), Miller Alonso Camargo-Valero ${ }^{1,3}$ (D), Adriana Matamoros-Veloza ${ }^{2}$ (D), \\ P. Andrew Sleigh ${ }^{1}$ and Catherine J. Noakes ${ }^{1}$ \\ 1 Institute of Public Health and Environmental Engineering, School of Civil Engineering, University of Leeds, \\ Woodhouse Lane, Leeds LS29JT, UK; M.A.Camargo-Valero@leeds.ac.uk (M.A.C.V.); \\ p.a.sleigh@leeds.ac.uk (P.A.S.); c.j.noakes@leeds.ac.uk (C.J.N.) \\ 2 School of Mechanical Engineering, University of Leeds, Woodhouse Lane, Leeds LS29JT, UK; \\ A.MatamorosVeloza@leeds.ac.uk \\ 3 Departamento de Ingeniería Química, Universidad Nacional de Colombia, Campus La Nubia, \\ Manizales, Colombia \\ * Correspondence: m.f.king@leeds.ac.uk; Tel.: +44-113-343-1957
}

Received: 29 September 2017; Accepted: 28 November 2017; Published: 1 December 2017

\begin{abstract}
Finding a non-pathogenic surrogate aerosol that represents the deposition of typical bioaerosols in healthcare settings is beneficial from the perspective of hospital facility testing, general infection control and outbreak analysis. This study considers aerosolization of dilute aqueous lithium chloride $(\mathrm{LiCl})$ and sodium chloride $(\mathrm{NaCl})$ solutions as surrogate tracers capable of representing Staphylococcus aureus bioaerosol deposition on surfaces in mechanically ventilated rooms. Tests were conducted in a biological test chamber set up as a replica hospital single patient room. Petri dishes on surfaces were used to collect the $\mathrm{Li}, \mathrm{Na}$ and $\mathrm{S}$. aureus aerosols separately after release. Biological samples were analyzed using cultivation techniques on solid media, and flame atomic absorption spectroscopy was used to measure $\mathrm{Li}$ and $\mathrm{Na}$ atom concentrations. Spatial deposition distribution of Li tracer correlated well with S. aureus aerosols ( $96 \%$ of pairs within a $95 \%$ confidence interval). In the patient hospital room replica, results show that the most contaminated areas were on surfaces $2 \mathrm{~m}$ away from the source. This indicates that the room's airflow patterns play a significant role in bioaerosol transport. $\mathrm{NaCl}$ proved not to be sensitive to spatial deposition patterns. $\mathrm{LiCl}$ as a surrogate tracer for bioaerosol deposition was most reliable as it was robust to outliers, sensitive to spatial heterogeneity and found to require less replicates than the S. aureus counterpart to be in good spatial agreement with biological results.
\end{abstract}

Keywords: bioaerosols; hospital; surface deposition; surrogate tracer; infection control

\section{Introduction}

Healthcare acquired infections (HCAI) are a globally important problem, with national deficits due to infections often running into the billions of US dollars [1]. At least five modes of infection transmission may occur at any given time within the hospital environment: direct contact [2], indirect contact [3], common vehicle [4], droplet [5] and pure airborne sub-micron particle transport [6]. For some infections like tuberculosis, which are exclusively transmitted through susceptible subjects inhaling the bacteria, the airborne route of transfer is relatively well documented [6-8]. However, the precise modes of transmission for many HCAI, such as methicillin resistant Staphylococcus aureus 
(MRSA) or Clostridium difficile, are still poorly understood, and it is thought that contaminated room surfaces may provide a route for patient infections [9-13].

Deposition of pathogen-laden bioaerosols can create reservoirs of environmental bioburden [12,14-18], and studies have demonstrated that ventilation rates affect hospital airborne microflora and contamination on surfaces [19-21]. Therefore, understanding the fate of aerial pathogens is of paramount importance. Sub-micron sized particles are thought to remain airborne for prolonged periods of time [22], while larger droplets $(>5 \mu \mathrm{m})$ are influenced by ventilation patterns, whereby the evaporation process followed by deposition may occur many meters from the initial source [23]. The environmental layout of a hospital room has been shown to have an impact on infection transmission, but biological experiments are only possible in specialist chambers [24,25]; in-vivo experimentation to discover where bioaerosols land in patient rooms is impossible using biological organisms [26]. Therefore, a non-biological surrogate that can faithfully mimic the trajectory of microorganisms in the indoor air is required.

A surrogate tracer in this current context is a particle, compound or organism that is used to determine the fate of the original pathogen/microorganism [27]. When selecting surrogates in an experimental setting, these should ideally represent the original microorganism's morphology, be resistant to environmental conditions, be non-toxic and non-pathogenic, be traceable and be quantifiable.

The aim of this study is to establish whether an aerosolized salt solution can effectively represent the deposition of a bioaerosol on surfaces in a room. The specific objectives are (a) to establish an experimental protocol for preparation and aerosolization of aqueous lithium chloride $(\mathrm{LiCl})$ or sodium chloride $(\mathrm{NaCl})$ as a surrogate tracer for aerosols containing S. aureus; (b) to quantitatively assess the deposition patterns of both aerosols in an environmentally controlled biological chamber; (c) to study the deposition on surfaces in a replica hospital single patient room; and (d) to assess the statistical agreement, sensitivity and replicability of the methodologies.

\section{Biological Surrogates}

Biological surrogates are categorized as either indicator or umbrella, whereby the former is a direct representative of another species [28]. The latter occurs typically in an ecological context where the existence of one species correlates with the existence of a population of other either undetectable or difficult to detect species. The identification of indicator surrogates such a coagulase positive Staphylococcus aureus to suggest the existence of methicillin resistant $S$. aureus in the same environment is common amongst hospital infection control staff [2,29]. Non-pathogenic strains of S. aureus (see Table 1) have been used experimentally to evaluate the fate of methicillin-resistant staphylococcus strains $[24,25,30]$. In the context of bioterrorism, the use of Bacillus anthracis (anthrax), a variety of similar non-pathogenic subspecies have been trialed in experimental facilities to investigate the fate of such bioaerosols [31]. A ubiquitous and phylogenetically similar Bacillus atrophaeus organism was used historically, but now it is realized that physical size and morphology alter bioaerosol behavior [32], and so this has been discarded in favor of Bacillus thuringiensis subspecies kurstaki. When viability of the species after surface disinfection is of interest, Bacillus atrophaeu proved to be more resilient than Bacillus anthracis, and although easy to culture, it is more susceptible to chlorine inactivation, so should not be used in this context [31]. Therefore, it is clear that choice of surrogate must be application specific.

Aerosol analysis techniques are abundant, ranging from real-time organism detection [33] to aerosol morphology identification [31], but hospital infection control is also interested in micron-sized particle surface deposition $[25,34]$.

Adenosine tri-phosphate (ATP) techniques quickly measure the relative luminescence of biological material on collected samples, and can offer a potential methodology for quantifying spatial surface contamination $[9,29,35]$. One of the main drawbacks (see Table 1) means that it cannot differentiate between organic material or viable and non-viable organisms, in addition to being 
non-organism sensitive. Fluorescent staining of bacteria prior to aerosolization has improved visual enumeration techniques allowing increased confidence in supervised computer image analysis [36]. Still, the problem of detecting viability remains.

Non-biological alternatives such as fluorescent latex spheres have been used successfully to test room air-tightness during a hospital post-occupancy study $[37,38]$ and while easy to enumerate microscopically, are not recoverable from the environment. While tracer gases including $\mathrm{SF}_{6}$ [39-42], $\mathrm{NO}_{2}$ [43-45] and $\mathrm{CO}_{2}[36,46]$ provide a simple and relatively inexpensive method of evaluating room leakage or contaminant transport, they are unable to offer the ability of measuring spatial deposition. Alternative methods including smoke particles and oil droplets have been used successfully as proxy bioaerosol surrogates $[40,47]$; however, neither can be evaluated quantitatively through deposition techniques. Ink or food colorant have been used as an estimate for deposition distance from source by coughs [48] and hand dryers [49], but offer only qualitative results. Fluorescein is a solid fluorescent tracer used quantitatively and qualitatively as a surrogate because it fluoresces at a specific narrow waveband. Due to its low solubility in water and sensitivity to ambient $\mathrm{pH}$, fluorescein must be dissolved using a polar solvent such as ethanol to ensure maximum dissolution. This usage means that aerosols produced using this solution will desiccate at a faster rate than water or mucous droplets, commonly found in hospital settings [22]. If it were to be aerosolized as a partially dissolved solute in water, the distribution of fluorescein particles on the aerosol surface may not be fully representative of microorganism bioaerosol [50]. However, one of its main drawbacks lies in the staining of surfaces, being hard to clean.

Tracers involving elemental metals, which dissociate well in solution are ideal candidates due to quantitative techniques available to enumerate concentrations [51]. Lithium halide compounds are found in negligible concentrations in background air, are highly soluble in water, and can be identified readily in parts per billion ( $\mathrm{ppb}$ ) concentrations using flame atomic adsorption spectroscopy (FAAS). This study investigates whether aerosolization and subsequent deposition of aqueous lithium chloride and/or sodium chloride droplets can represent the spread of bioaerosols containing S. aureus.

Table 1. Commonly-used tracer and surrogate techniques in indoor air experimental methodology.

\begin{tabular}{|c|c|c|c|c|}
\hline Surrogate Name & Used for & Advantages & Disadvantages & Reference \\
\hline $\begin{array}{l}\text { Staphylococcus } \\
\text { aureus }\end{array}$ & $\begin{array}{l}\text { MRSA (Methicillin } \\
\text { Resistant } \\
\text { Staphylococcus } \\
\text { aureus) }\end{array}$ & $\begin{array}{l}\text { Non-pathogenic to } \\
\text { healthy individuals and } \\
\text { morphologically } \\
\text { identical to MRSA. } \\
\text { Readily grows on } \\
\text { standard nutrient agar. }\end{array}$ & $\begin{array}{l}\text { Requires culturing } \\
\text { period and counting } \\
\text { colonies by hand or } \\
\text { machine. Cannot be } \\
\text { used in-vivo locations }\end{array}$ & {$[24,25]$} \\
\hline $\begin{array}{c}\text { Bacillus } \\
\text { thuringiensis subsp. } \\
\text { kurstaki }\end{array}$ & Bacillus anthracis & $\begin{array}{l}\text { Non-pathogenic and } \\
\text { morphologically } \\
\text { representative of } \\
\text { microorganism }\end{array}$ & $\begin{array}{l}\text { Cannot be used in } \\
\text { in-vivo locations }\end{array}$ & {$[31]$} \\
\hline MS2 phage & $\begin{array}{l}\text { Viruses, e.g., } \\
\text { rotavirus }\end{array}$ & $\begin{array}{l}\text { Representative of typical } \\
\text { larger viruses }\end{array}$ & $\begin{array}{l}\text { Requires specialist } \\
\text { microbiological and } \\
\text { microscopy skills. } \\
\text { Cannot be used in } \\
\text { in-vivo locations. }\end{array}$ & {$[52-54]$} \\
\hline Oil droplets & (Bio)aerosols & $\begin{array}{l}\text { Specific size droplets can } \\
\text { be produced. }\end{array}$ & Hard to clean surfaces & [47] \\
\hline $\begin{array}{l}\text { Fluorescent latex } \\
\text { spheres }\end{array}$ & (Bio)aerosols & $\begin{array}{l}\text { Quantitative airborne } \\
\text { and surface counts. } \\
\text { Consistent size. }\end{array}$ & $\begin{array}{l}\text { Cannot retrieve spheres, } \\
\text { latex is an allergen. }\end{array}$ & [55] \\
\hline
\end{tabular}


Table 1. Cont.

\begin{tabular}{|c|c|c|c|c|}
\hline Surrogate Name & Used for & Advantages & Disadvantages & Reference \\
\hline Fluorescein & $\begin{array}{l}\text { General purpose } \\
\text { tracer }\end{array}$ & $\begin{array}{l}\text { Highly soluble. } \\
\text { Quantitative airborne and } \\
\text { surface contamination. } \\
\text { Fluorescence easy to detect }\end{array}$ & $\begin{array}{l}\text { Quantitative correlation to } \\
\text { microorganisms unknown. } \\
\text { Requires expert preparation } \\
\text { and can cause anaphylaxis } \\
\text { in up to } 6 \% \text { of exposed. } \\
\text { Hard to clean. }\end{array}$ & [50] \\
\hline $\begin{array}{c}\text { Fluorescent } \\
\text { bacterial staining }\end{array}$ & $\begin{array}{l}\text { Airborne and } \\
\text { surface } \\
\text { contamination }\end{array}$ & Gives total bacterial count. & $\begin{array}{l}\text { Requires specialist } \\
\text { microbiological and } \\
\text { microscopy skills. Does not } \\
\text { give total viable count. }\end{array}$ & {$[37,56]$} \\
\hline Smoke sticks & Airflow movement & Easy to use, leaves no trace & $\begin{array}{c}\text { Qualitative results only. Use } \\
\text { of laser light to track } \\
\text { particles requires sealed } \\
\text { opaque room. }\end{array}$ & {$[24,57]$} \\
\hline $\mathrm{CO}_{2} / \mathrm{NO}_{2}$ & $\begin{array}{l}\text { Airborne } \\
\text { contaminant } \\
\text { transport }\end{array}$ & $\begin{array}{c}\mathrm{CO}_{2} \text { canisters are } \\
\text { abundant and sensors are } \\
\text { cheap and accurate }\end{array}$ & $\begin{array}{l}\text { Exists in background } \\
\text { concentrations so needs high } \\
\text { levels. Asphixiant so cannot } \\
\text { be used in situ. }\end{array}$ & {$[45,58]$} \\
\hline $\begin{array}{c}\text { Ink/food } \\
\text { colorant/Rhodamine }\end{array}$ & $\begin{array}{c}\text { Surface } \\
\text { contamination }\end{array}$ & Cheap and visual & Qualitative results & {$[23,49]$} \\
\hline $\begin{array}{c}\text { Schlieren } \\
\text { photography }\end{array}$ & Airflow movement & $\begin{array}{l}\text { Safe for human } \\
\text { participants }\end{array}$ & $\begin{array}{l}\text { Small field of view and } \\
\text { qualitative results. }\end{array}$ & {$[40,59]$} \\
\hline
\end{tabular}

\section{Methodology}

A mechanically ventilated biological chamber was used to investigate separately the deposition of $\mathrm{LiCl}$ (aq), $\mathrm{NaCl}$ (aq) and a bioaerosol containing S. aureus onto Petri dishes distributed on the floor of the chamber (Figure 1a). All the experiments were performed under similar conditions in an empty chamber (only petri dishes on the floor) using $6 \mathrm{ach}^{-1}$ of ventilation rate, and the aerosols were released from the center of the chamber. Following this, a replica of a single patient hospital room was created within the chamber comprising a bed from which the aerosols were released.

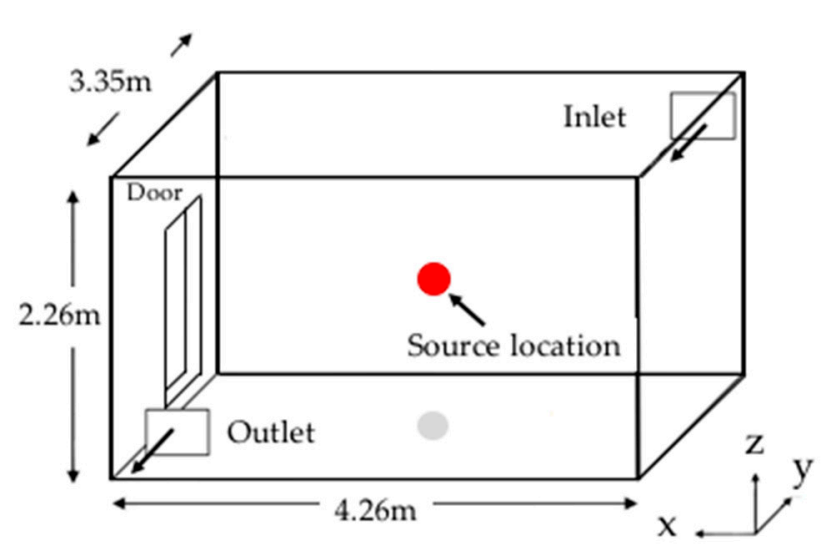

(a)

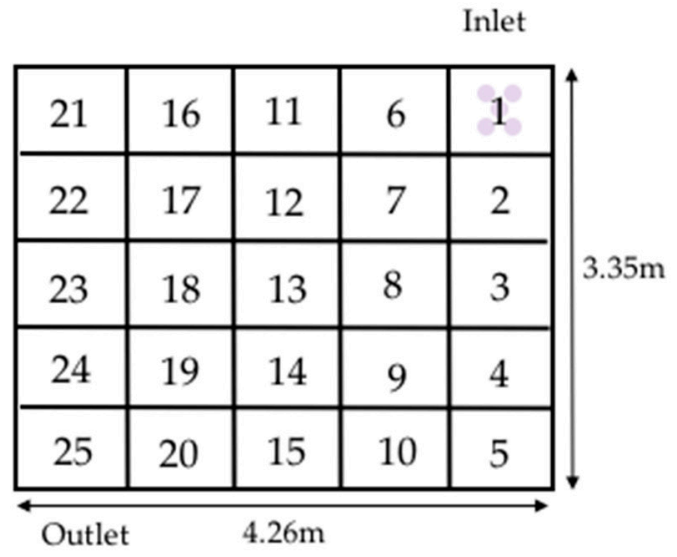

(b)

Figure 1. (a) Empty chamber geometry indicating ventilation and aerosol release location; (b) Zone location on floor of empty chamber with representative Petri dish arrangement in zone 1.

\subsection{Empty Chamber}

Experiments were conducted in the environmentally controlled, negatively pressurized, aerobiology chamber at the University of Leeds according to methodology set out by King et al. [25]. Dimensions are 
similar to a UK hospital single patient or isolation room: $4.26 \mathrm{~m}(\mathrm{~L}) \times 3.36 \mathrm{~m}(\mathrm{~W}) \times 2.26 \mathrm{~m}(\mathrm{H})$. All walls are well insulated and considered adiabatic. External air was HEPA (high efficiency particulate air) filtered before being conditioned by a humidifier and heater. Ventilation inlet and outlet can be seen in Figure 1a. Air was supplied through a high-level wall mounted grille $(0.38 \mathrm{~m} \times 0.25 \mathrm{~m})$. Extraction of air was at a low-level diagonally opposite, through a grille of the same design (Outlet).

A standard ventilation rate of six air changes per hour $\left(\mathrm{ach}^{-1}\right)$ was used and verified using a balometer (Model PH721, TSI Incorporated, Shoreview, MN, USA). This is similar to UK hospital ventilation guidelines [60]. Inlet air temperature $\left(21.8 \pm 1{ }^{\circ} \mathrm{C}\right)$, humidity $(60 \% \pm 7 \%)$ were controlled throughout the experiments. Figure $1 \mathrm{~b}$ shows the zoning of the floor. Access to the chamber was through a hermetically sealed door and no lights were on during experiments.

\subsection{Hospital Single Room Replica}

A hospital single bed room was set up in the chamber as per Figure 2 including: a chair, table, medicine preparation counter (called worktop) and a bed (split into bed-bottom, bed-middle and bed-top). A Deutsche Institüt für Normung supine heated cylinder (DIN-man) [47] ( $1.3 \mathrm{~m}$ in length $\times 0.35 \mathrm{~m}$ in diameter) is shown in Figure 2a. This is a hollow cylinder which is representative of a human heat output of $56 \mathrm{~W} / \mathrm{m}^{2}$ by the use of three incandescent bulbs located inside the aluminum hull. The perforated red sphere in Figure $2 b$ is a devise for bioaerosol dispersion into the chamber, but it was not used in this particular set of experiments.

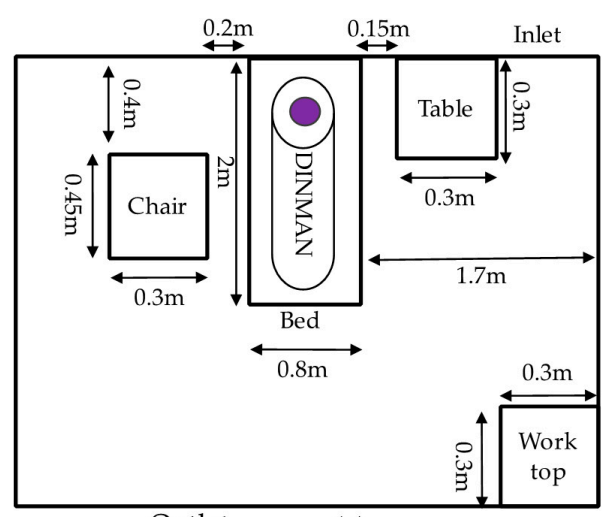

Outlet (a)

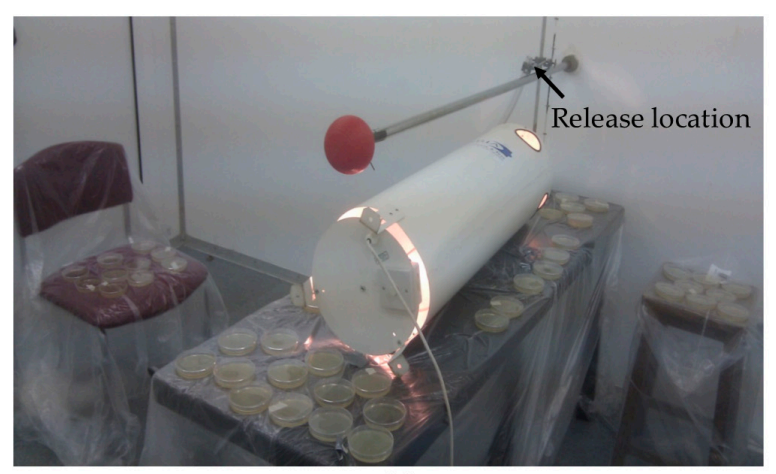

(b)

Figure 2. (a) Experimental layout in the chamber for hospital room; (b) Photo of furniture, DIN-manset-up and release location.

\subsection{Aerosol Generation}

Staphylococcus aureus was chosen as the bacteriological agent given its ability to grow on general purpose media with ease and relevance to HCAI $[60,61]$. The $S$. aureus culture was incubated in nutrient broth (Oxoid, UK) for $24 \mathrm{~h}$ at $37^{\circ} \mathrm{C}$. Subsequent dilution tests showed the concentration to be circa $10^{11}$ organisms per $\mathrm{mL}$. A $10 \mathrm{~mL}$ aliquot of the pure culture was aseptically removed and suspended in $100 \mathrm{~mL}$ of sterile distilled water, which was the preferred suspension medium since it did not produce foaming of the suspension during nebulization. Lithium chloride ( $\mathrm{LiCl})$ and sodium chloride $(\mathrm{NaCl})$ were used as non-toxic surrogate tracer compounds. $\mathrm{LiCl}$ and $\mathrm{NaCl}$ solutions were prepared at $5 \%$ by adding $12.5 \mathrm{~g}$ of each compound to $250 \mathrm{~mL}$ of deionized water.

Surrogate and biological aerosols were released using a pre-autoclaved six jet Collison nebulizer (CN 25, BGI Inc., Butler, NJ, USA), which was attached to the inlet port of the chamber, allowing for careful control and monitoring of the aerosolization process [25]. The nebulizer utilizes a separate pump, pressure regulator and air flow meter operating at a flow rate of $8 \mathrm{~L} \mathrm{~min}^{-1}$ to deliver HEPA filtered air. Manufacturer's data from BGI indicate the size distribution of particles ejected during the process to have a mean mass diameter of $2.5 \mu \mathrm{m}$ and a standard deviation of $1.8 \mu \mathrm{m}$; however, 
droplet size distribution may vary through evaporation and the experimental set-up [26]. For the empty chamber case, aerosols were injected through a port with circular orifices $(0.2 \mathrm{~cm}$ in diameter $)$ that allows isotropic injection (red port in Figure $2 \mathrm{~b}$ ). For the hospital room replica, aerosols were injected at the head of the cylinder through a plastic tube of diameter $2.5 \mathrm{~cm}$, which represents a cough condition from a patient. A laser particle counter (Kanomax 3886 Optical Sciences Ltd., Northampton, UK) was used in the bulk air to check when steady state conditions were achieved with regard to air flow distribution and to record the dominant particle sizes throughout the experiment. No significant size distribution discrepancies were noted through using different tracer methods $(p=0.31)$.

\subsection{Sample Collection and Processing}

Prior to the experiment, the biological chamber was set-up and ventilation turned on. Petri dishes ( $9 \mathrm{~cm}$ in diameter with agar media) were laid out on the respective surfaces with lids on and particle size was monitored for one hour before running the experiments. Once a steady state particle count had been reached for all size ranges, an operator wearing full-body overalls and respirator entered the chamber to remove the lids of the Petri dishes to allow for aerosol deposition. Then, the nebulizer pump was turned on and run for $30 \mathrm{~min}$. The nebulizer was then turned off and the chamber allowed to vent for a further $30 \mathrm{~min}$. An operator then re-entered the chamber slowly and placed lids carefully on the Petri dishes. In order to ensure minimal contamination, a scoping study was initially run to establish door opening angle and speed sufficient for entrance of the operator but which minimized potential environmental contamination.

For the empty chamber experiments, five Petri dishes were co-located at the center of each of the sampling grid area in a circular arrangement. In the hospital single patient room experiment instead, twelve Petri dishes were placed on each surface of interest (see Figure $2 b$ ). $\mathrm{LiCl}$ and $\mathrm{NaCl}$ experiments were conducted separately using sterile, empty Petri dishes in the same locations. All biological samples were taken on Tryptone soya agar (Oxoid, UK) and incubated at $37{ }^{\circ} \mathrm{C}$ for $24 \mathrm{~h}$. The controlled chamber conditions ensured that no other species were present. After incubation, colonies of Staphylococcus aureus were counted by visual inspection using backlighting of Petri dishes and manual enumeration; colony agglomerates were counted as one colony in cases where individual colonies were undistinguishable. Petri dishes showed no visible contamination from environmental microorganisms.

$\mathrm{Li}$ and Na-containing Petri dishes were swilled with $25 \mathrm{~mL}$ of $1 \% \mathrm{HCl}$ and scrubbed before being poured into vials. $\mathrm{Li}$ and $\mathrm{Na}$ concentrations were quantified using flame atomic absorption spectroscopy (FAAS) (ContrAA 700, Analytik Jena, Jena, Germany) [51]. Samples were prepared as per manufacturer instructions by adding $250 \mu \mathrm{g}$ of a Cs and La chloride buffer (Analytik Jena, Jena, Germany) to each vial. During the analysis, the instrument was calibrated before and after ten samples with standard solutions in the same matrix.

\subsection{Statistical Analyis}

To compare the salt and biological methods, scatter plots, pairwise comparison plots and Kendall-Tau correlations were performed using standardized values through Equation (1). Results for each surrogate tracer are reported as standardized by sample mean $(\bar{X})$ and standard deviation $(S)$ :

$$
\frac{\left(x_{i}-\bar{X}\right)}{S}
$$

where $x_{i}$ is the mean individual tracer concentration per five Petri dishes at each location $i$.

A Kolmogorov-Smirnov test was used to investigate whether sample distributions could be considered similar. Additionally, to compare samples in a grouped manner, the Bland-Altman analysis, which is a standard method for visualization of instrumental agreements and discrepancies [61], was used to test agreement between techniques in this study. This method plots the difference between the techniques against the average of both. As both sampling techniques use different 
absolute units ( $\mathrm{cfu} / \mathrm{cm}^{2}$ in the case of S. aureus and parts per billion (ppb) in the case of $\mathrm{LiCl}$ or $\mathrm{NaCl}$ ), normalization of the results with respect to group mean was performed. This method is used in addition to conventional correlation analysis to give further insight into potential intrinsic sampling bias. Limits of agreement were determined by $95 \%$ confidence intervals (CI) of the mean of the differences of deposition estimates by each solute method compared to the biological experiment. Normality and homoscedacity of random errors of each experiment are assumed for parametric determination of the CI [62]. Normalization of values allows for visualization of trends in the data but makes agreement dependent on normalization constant.

To assess experimental replicability, inter-group Kruskal-Wallis tests were used in conjunction with Bland-Altman agreement bias. As all experimental replicates were done concurrently (i.e., all five Petri dishes were co-located at the center of the sample grid), each one was assigned a random group from one to five and so small variations between individual Petri dish location in each zone can be ignored. All statistical analysis was carried out in R (version 3.4.1).

\section{Results}

S. aureus counts on Petri dishes ranged from 3 to $10 \mathrm{cfu} / \mathrm{cm}^{2}$ with an average of $5 \mathrm{cfu} / \mathrm{cm}^{2}$, which is typical of UK hospital surface bioburden concentrations [63]. $\mathrm{LiCl}$ concentrations ranged from 8 to $23 \mathrm{ppb}$ with an average of $12 \mathrm{ppb}$ and a standard deviation of $0.3 \mathrm{ppb}$. $\mathrm{NaCl}$ concentrations ranged from 103 to $585 \mathrm{ppb}$ with an average of $271 \mathrm{ppb}$ and standard deviation of $6 \mathrm{ppb}$. Experimental measurement sensitivity of the FAAS technique was calibrated with reference Li samples of 0 to $100 \mathrm{ppb}$ and predictions were found to be within $0.65 \%$ of samples. Error was found to be uniform for all samples tested $(n=125)$ and below $6 \%$.

Steady state minus background airborne particle concentrations for each of the different measured particle size ranges for all experiments captured by the laser particle counter were as follows: $<0.3 \mu \mathrm{m}$ : $6.6 \times 10^{7} / \mathrm{m}^{3}, 0.3 \mu \mathrm{m} \leq \mathrm{x}<0.5 \mu \mathrm{m}: 5.2 \times 10^{7} / \mathrm{m}^{3}, 0.5 \mu \mathrm{m} \leq \mathrm{x}<1 \mu \mathrm{m}: 3.8 \times 10^{7} / \mathrm{m}^{3}, 1 \mu \mathrm{m} \leq \mathrm{x}<3 \mu \mathrm{m}:$ $7 \times 10^{6} / \mathrm{m}^{3}$ and $3 \mu \mathrm{m} \leq \mathrm{x}<5 \mu \mathrm{m}: 4.37 \times 10^{5} / \mathrm{m}^{3}$, indicating that the predominant particle size was in the sub-micron range. This appears to be representative of "small" particle size ranges and quantities found by Hathway et al. [34] in a UK hospital multi-bed ward environment.

The results below show standardized contour plots using Equation (1). The Kolmogorov-Smirnov test could not reject the null hypothesis that normalized $\mathrm{LiCl}, \mathrm{NaCl}$ and $\mathrm{S}$. aureus which came from distributions with similar shapes $(\mathrm{d}=0.16, p=0.48)$; however, visualization of the data in contour plots depicted in Figure 3 suggests that the $S$. aureus deposition tends to be less uniform than either $\mathrm{Li}$ or Na deposition. In general, all correlation methods showed that highest deposition occurred in the center of the grid sampling areas in Figure 1, (13 and 14) and towards the ventilation outlet (15 to 20). A correlation between bioburden and salt concentration was found, where the slope of the line was statistically significantly different from zero for $\operatorname{LiCl}(p<0.001)$, but not for $\mathrm{NaCl}(p=0.131)$.
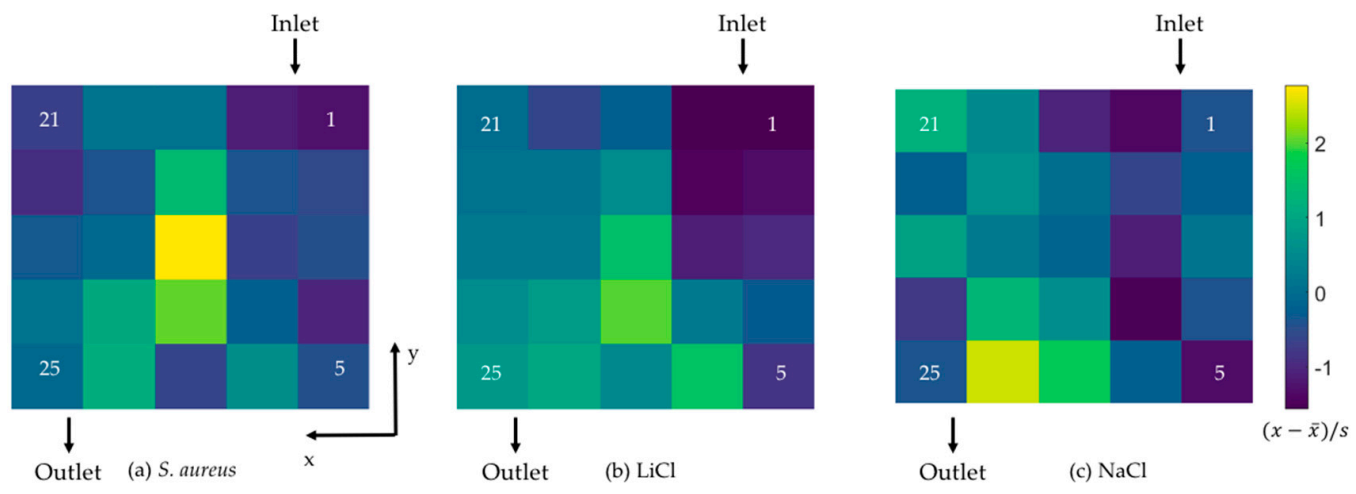

Figure 3. Floor spatial deposition maps of (a) normalized S. aureus; (b) normalized $\mathrm{LiCl}$; (c) normalized $\mathrm{NaCl}$. 
Figure $3 \mathrm{a}, \mathrm{b}$ show location comparisons for both techniques, with $\mathrm{LiCl}$ concentrations being within one standard deviation of each S. aureus counterpart.

The scatterplot in Figure 4a suggests that the Li surrogate aerosol overestimates the S. aureus concentrations when the deposition value is higher than the group mean but underestimates it when it is lower than the group mean. The scatterplot of the Na surrogate aerosol vs. S. aureus in Figure $4 \mathrm{~b}$ shows a predominantly uniform distribution of $\mathrm{NaCl}$ concentrations. Bland-Altman plots are used (see Figure 5) to plot the average of two measurement techniques against their difference in order to investigate intrinsic bias or deviation. For a measurement technique to replicate another faithfully, these graphs should look randomly distributed about the horizontal and vertical axes. Figure 5 suggest no intrinsic measurement bias exists between either of the sampling techniques as data are evenly distributed about the x-axis. Li data agrees better than $\mathrm{Na}$ with the $\mathrm{S}$. aureus distribution in spatial terms, as only 1 out of the 25 values are outside the $95 \%$ confidence intervals ( -0.317 to 0.317 ), whereas for $\mathrm{NaCl} 2$ values are out of $25(\mathrm{CI}=-0.58$ to 0.58$)$. This is corroborated by visual inspection of Figures 3 and $4 a, b$. It is also worth noting that the outliers exist when deposition quantities are higher (see Figure 5a,b).

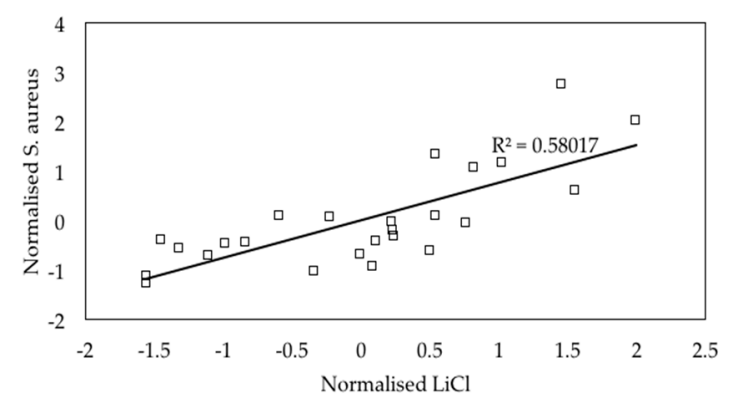

(a)

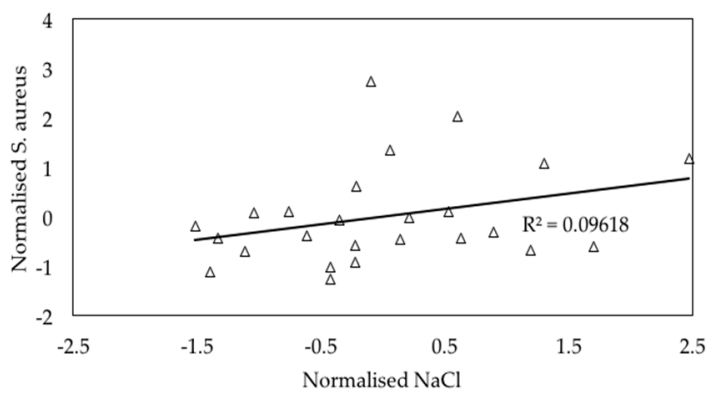

(b)

Figure 4. Linear regression of (a) $\mathrm{LiCl}$ on S. aureus and (b) $\mathrm{NaCl}$ on S. aureus.

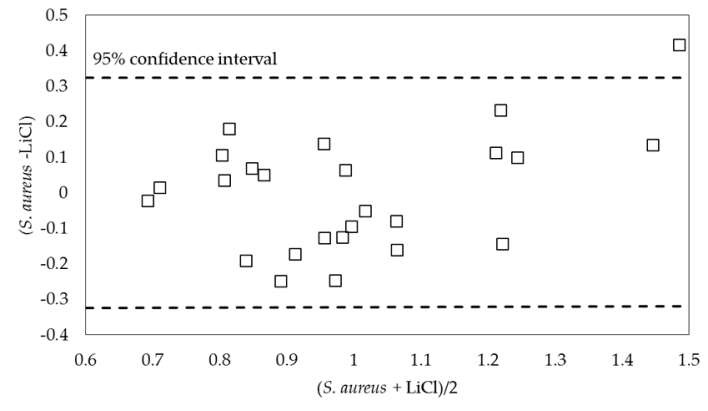

(a)

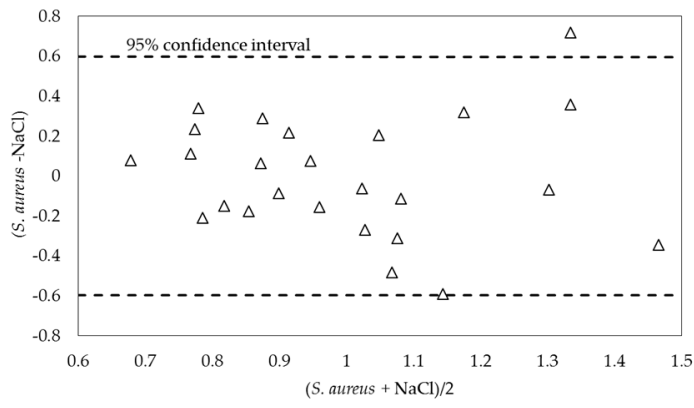

(b)

Figure 5. Bland-Altman agreement plots (a) S. aureus vs. LiCl, (b) S. aureus vs $\mathrm{NaCl}$.

\subsection{Precision of Methodology}

Figure 6 shows the standard deviations of biological and salt samples plotted against each other. A 1-to-1 relationship line is plotted on both graphs for visual comparison. Standardized S. aureus values had significantly higher variance than equivalently standardized $\mathrm{LiCl}$ or $\mathrm{NaCl}$ concentration ( $p<0.01$; one-tailed Wilcoxon signed-rank test on paired samples), placing $100 \%$ of the samples above the red line of identity (see Figure $6 a, b$ ). This observation advocates that the outliers with negative values shown in Figure 5a,b were mostly caused by the high variability in S. aureus counts rather than in salt solute concentrations. Skewness of $S$. aureus sample values was significantly higher for S. aureus $=1.21$ vs. $\mathrm{LiCl}=0.04$ and $\mathrm{NaCl}=0.56(p<0.01)$, indicating that $S$. aureus deposition tended to be more negatively skewed (i.e., data points tend to be lower than higher, but some extreme high 
counts existed in small numbers). Therefore, the $S$. aureus method is more susceptible to outliers across samples than the salt solute method.

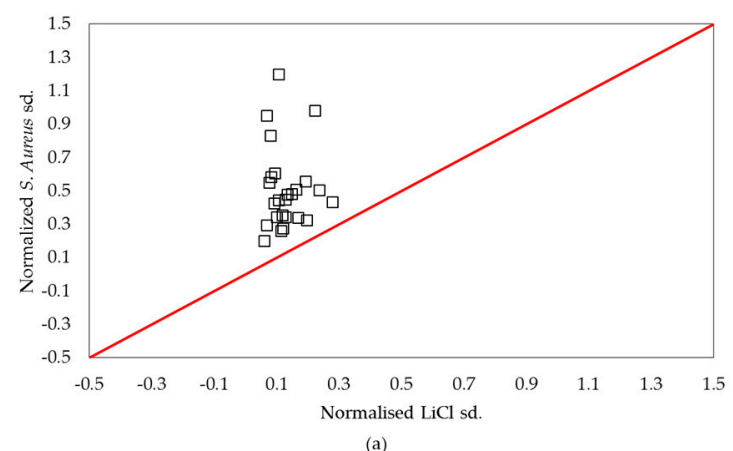

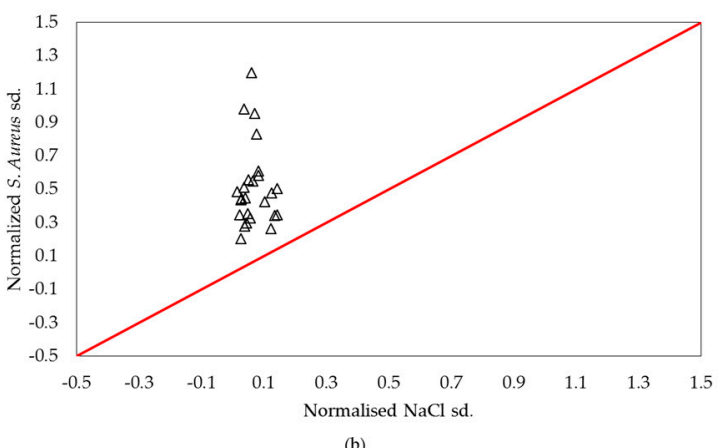

(b)

Figure 6. Plots of normalized standard deviation (sd.) for (a) S. aureus vs. $\mathrm{LiCl}$ (b) S. aureus vs. $\mathrm{NaCl}$. Solid red line indicates 1-to-1 relationship.

\subsection{Replicability and Sensitivity of Experiments}

To investigate how many Petri dishes (out of five) were required to produce replicable experimental results at each grid location, an intra-group Kruskal-Wallis test was used to compare raw experimental values for $\mathrm{S}$. aureus, $\mathrm{LiCl}$ and $\mathrm{NaCl}$. No statistically significant differences between median deposition concentrations could be found between groups of twenty-five Petri dishes $(p=0.53)$. However, to test the minimum required number of replicates for each method to attain statistical stability, Kolmogorov-Smirnov tests were carried out. Results showed that the spatial distribution did not come below a 5\% tolerance threshold of the mean until five $S$. aureus samples were used at each grid location $(p=0.45)$. This is highlighted by Bland-Altman agreement plots showing that $S$. aureus replicates tend to agree better at lower cfu values. At worst, 3 out of 25 co-located Petri dishes lay outside of the $95 \%$ confidence interval. This was found when only two replicates were used and in terms of percentage difference of cfu with respect to the mean, this was approximately $23 \%$ difference. At five replicates, this is reduced to $11 \%$, with two samples lying outside of the $95 \%$ CI. Therefore, at least five Petri dishes are required for biological sampling to represent the spatial deposition patterns. When only one Petri dish is used at each grid location for the salt solutes, agreement is seen to be right skewed, showing better agreement for lower concentrations. This phenomenon disappears when two Petri dishes were used $(p<0.01)$. Therefore, two replicates are required for the $\mathrm{LiCl}$ solute experiments to be all within $95 \% \mathrm{CI}$ but at least five are required for S. aureus. This is has been noted in current literature with one study requiring a minimum of six replicates and a maximum of fifteen [56].

\subsection{Single Patient Room Experiment}

Figure 7 shows the comparison between normalized biological and salt deposition values of the six surfaces in the hospital single patient room replica (similar to [25]): bedside table, chair, worktop and bed split into three parts. The Kruskal-Wallis non-parametric test showed that the intra-group deposition differences were statistically significant $(p=0.0046)$. Both $\mathrm{LiCl}$ and $\mathrm{NaCl}$ values were within one normalized standard deviation of $S$. aureus values as seen by the error bars in Figure 7. Biological deposition showed, however, higher overall normalized standard deviation than both $\mathrm{LiCl}$ and $\mathrm{NaCl}$ ( 0.86 vs. 0.53 and 0.36 respectively). Both $\mathrm{Li}$ and $\mathrm{Na}$ surrogate aerosols gave a good approximation to the S. aureus spread, where the best comparison was found at the near-patient surfaces (table, bed and chair).

All methods predicted the highest deposition on the worktop, with $\mathrm{LiCl}$ returning 1.76 standard deviations higher than the group mean, 1.59 for $S$. aureus and 1.16 for $\mathrm{NaCl}$ respectively. Conversely, the lowest deposition quantities were found on the bottom part of the bed ( . aureus $=1.12, \mathrm{LiCl}=0.86$ and $\mathrm{NaCl}=0.47$ standard deviations less than each group's mean). Both the table and the chair 
showed 35\% above average deposition but could not be statistically distinguishable $(p=0.54)$, whereas the bed as a whole showed $20 \%$ lower values compared to the former two $(p=0.04)$. Although the aerosol release location was at the patient head, convective plumes above the DIN-man may have promoted transport away from the source, which was also noted in King et al. [25]. This corresponds to entrainment of aerosols in the inlet airstream, being transported towards the worktop and equating to highest quantitative deposition for all tracers.

Deposition difference was found between separate sections of the bed; for S. aureus, $11 \%$ more cultures were retrieved from the top of the bed compared to the middle and $33 \%$ more than the bottom. For the $\mathrm{LiCl}$, this was $5 \%$ and $19 \%$ respectively, which upholds the trends but under predicts the magnitude of difference. $\mathrm{NaCl}$ samples were found to be much more homogeneously spread with differences less than $1 \%$ between bed sections. Standard deviations were generally lower for $\mathrm{NaCl}$ in comparison to $\mathrm{LiCl}$, as can be seen by error bars in Figure 7 .

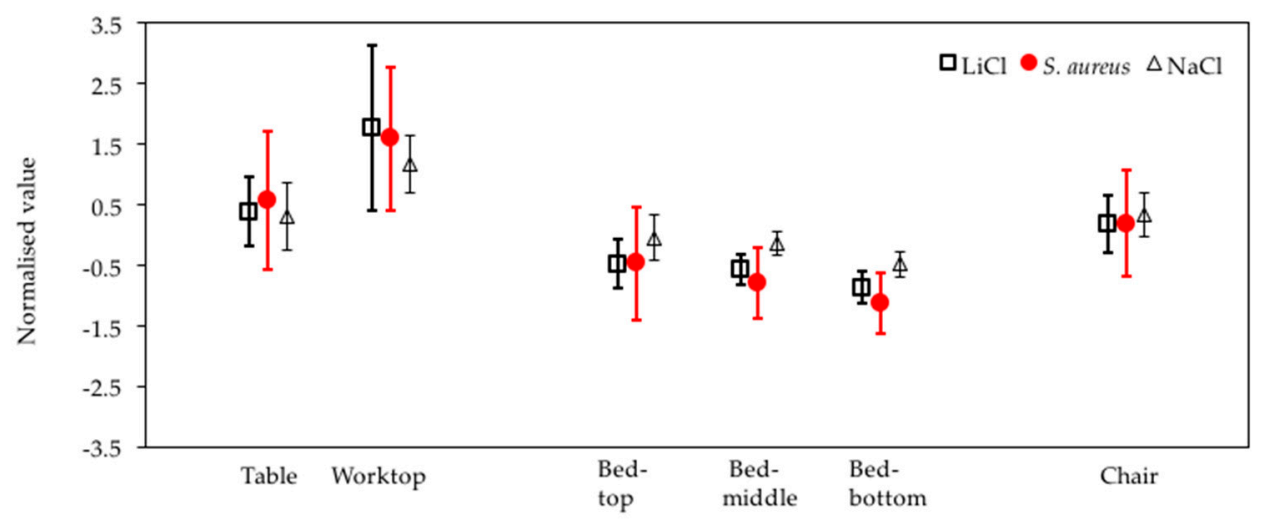

Figure 7. Comparison of normalized surface deposition for $\mathrm{LiCl}, \mathrm{NaCl}$ and S. aureus. Error bars represent one normalized standard deviation units from the mean.

\section{Discussion}

It is desirable to be able to produce a realistic assessment of the fate of microorganism-laden aerosols in the indoor environment in order to aid hospital room design, cleaning practice and risk assessment. Substantial effort is found in current literature and infection control practice to introduce inorganic tracers, biological surrogates and inert gases to be able to inform on patient risk and exposure assessments (see Table 1). The results presented here suggest that it is feasible to use $\mathrm{LiCl}$ to predict realistic spatial deposition of bioaerosol, and this work supports and validates the use of surrogate techniques for representing bioaerosol behavior in the indoor environment.

\subsection{Empty Room}

The first experiment represents a controlled condition where the influence of the ventilation flow on bioaerosol behavior could be investigated in isolation. S. aureus and salt solutes were sprayed in separate experiments and efforts were made to ensure experimental reproducibility. Comparison between the Li surrogate and the S. aureus aerosol deposition patterns showed that peak concentrations were slightly underpredicted by the salt, but on average a good distribution comparison was achieved far from the source. This has some implications for potential risk assessment, whereby areas that thought to be clean far from the patient may actually become contaminated from airborne particles.

Conversely, Na data did not show a statistically significant correlation with the biological colony count. High concentrations of sodium in the background might account for this in part, with a $6 \%$ error margin consistent with FAAS measurement bias for sodium atoms potentially contributing to the rest. $\mathrm{NaCl}$, however, was found to compare better with $\mathrm{LiCl}$ than $\mathrm{S}$. aureus in terms of concentration 
distribution shape parameters as well as qualitative comparison in Figure $3 b, c$. As such, $\mathrm{NaCl}$ might be best used during a scoping study but could not be sufficiently reliable for exposure risk estimates.

Overall, the results suggest slightly higher deposition close to the source, possibly due to the largest particles depositing out of the air before evaporating. Nevertheless, deposition is apparent across the room, indicating the combined influence of air movement and gravitational settling of small sub-micron diameter particles.

\subsection{Single-Bed Room}

The second experiment added complexity and realism by including a hospital single patient room layout, furniture and a human representative heat source. In this case, the patient was immobile and the contaminant was released at a consistent rate. This could be considered comparatively similar to an isolation room, but it is clear that healthcare workers would significantly disturb the airflow patterns within the room and, potentially, cause particle deposition. Despite the simplifications, it is still worth noting that airborne microorganism-laden droplets can measurably deposit onto surfaces across a room, whereby creating environmental contamination far from the release location.

Spatial variation in deposition was compared between relevant furniture surfaces including the bed, bedside table, a worktop for medicine preparation and a visitor's chair. Both $\mathrm{Li}$ and $\mathrm{Na}$ concentrations followed the same trend as biological deposition with similar heterogeneity as that was found in results for the empty room. On the other hand, the actual deposition of bacteria in terms of concentration should be derived from the biological studies directly.

The highest degree of variation was found for Na data, especially for surfaces far from the release source. All methods of deposition showed that the top of the bed was comparatively more contaminated than either the middle or the bottom. This could be because of the polydispersed nature of the aerosolization process, whereby larger droplets deposit close to the source, but smaller particles evaporate and are transported meters from the original release point [22]. This has important implications for hospital patient care and cleaning regimes.

In comparison to the empty chamber, where samples were collected from the floor, less spatial variation was seen but comparatively more than average deposition was found in the lower right-hand corner of the room (worktop surface). This surface was found to be the most contaminated of all surfaces measured in the hospital patient room replica. Our previous study [25] showed that, in terms of ventilation inlet and outlet locations, the airflow patterns in the room were dominated by the inlet air speed $(0.6 \mathrm{~m} / \mathrm{s})$ which created a jet stream which declined towards the wall at an angle of $17.5^{\circ}$ impacting above the worktop. As a result, it could be hypothesized that aerosols became vertically elevated by the DIN-man's thermal plume, desiccating, and rapidly being entrained by the inlet jet of air. This would explain the higher deposition concentrations found in that location for all three experimental methodologies.

$\mathrm{Na}$ data captured the general trend of the deposition but quantitatively tended to show consistently lower spatial variation. The best comparison was found in close proximity to the release point at the top of the bed. As a consequence, this could be seen as a conservative estimate for local contamination only. The Li data, on the other hand, were able to capture the peak deposition concentrations close to the patient (bed and table), which could be critical in hospital cleaning, but overestimated biological colony counts further away by $20 \%$ (worktop). Although S. aureus is a ubiquitous organism found naturally in the environment, its viability is susceptible to desiccation and shear forces experienced during flight or deposition [63]. As a result, over prediction by the salt tracers on the worktop may not be an intrinsic property of the salt distribution but be as a result of loss of viability of a significant quantity of the biologic colonies due to the higher shear forces exerted by the inlet airstream in the vicinity of this surface. At relatively high colony counts on each plate ( $>400 \mathrm{cfu} /$ plate), the chance of clustering increases exponentially and therefore a percentage of agglomerated colonies would be counted as a single unit. As a result, serial dilution or approximation 
by normal distribution could be used as a simplification, similar to methodology proposed by Johnson and Lynch [37].

\subsection{General Observations}

Bioaerosols that are typically smaller than $10 \mu \mathrm{m}$ are thought to remain airborne, whereby deposition mechanisms occur mainly though collision between droplets or direct contact with surfaces [22]. This study has shown that a substantial quantity of the deposited particles may have been in the micron or submicron size range, which has also been reported in modern literature [22,64]. As a result, certain infection inducing microorganisms that were thought to be predominantly airborne such as influenza or varicella, could deposit onto surfaces many meters way from the infectious source. This study uses a Collison nebulizer with a predefined size-range, therefore validity of the method can only be assumed for these sizes.

Contamination during experiments can be a factor in biological experiments either from other ubiquitous microorganisms, the operator themselves, resuspension from surfaces or other airborne sources. Inorganic tracers, on the other hand, are not prone to environmental degradation, and so can be transported and stored for prolonged periods of time without loss of concentration. However, as indicated above, natural background concentrations can be an issue for some substances.

Pathogenic and non-pathogenic surrogates have been used previously to study biological transport and decay. This current method cannot measure viability over time but since current hospital cleaning practices suggest that high touch surfaces should be cleaned once every eight hours, it is reasonable to assume that significant biological bloom is unlikely. As a consequence, the Li method may still overestimate viable colony surface contamination.

\subsection{Implications}

While spatial variation depends on layout, the results here and in previous work [65] suggest there is clear potential for small diameter $(<2.5 \mu \mathrm{m})$ particles to play a role in transmission of infection through indirect contact routes. This is an important consideration as such particles are routinely regarded as airborne and hence controlled through ventilation rather than cleaning. Moreover, these small particles are usually only considered of concern where the pathogen is classed as possibly capable of direct airborne transmission, for example chickenpox, measles or influenza. The deposition of viable bioaerosols in this study adds support to the hypothesis that airborne dispersion may play a role in non-respiratory infections including MRSA [66]. Implications for cleaning are far reaching and a good example of this is the case of noroviral [67] or C. diff induced vomiting. Emesis would be cleaned by staff but airborne micron-sized pathogen-laden particles may deposit meters away contaminating surfaces outside the patient zone.

In the context of current hospital overcrowding, a sudden bioterror incident or outbreak of a highly virulent strain of influenza could mean that rooms that were not designed for isolation purposes may have to receive highly infectious patients. As Li is not absorbed through the skin and exposure to concentrations described in the current study are not known to pose a significant risk to humans, the use of $\mathrm{Li}$ as an innocuous tracer in an empty hospital room would not require special room decontamination. As a result, it could be used to identify potential risk to staff from transport of bioaerosols from the patient location to outside of a "safe zone".

\section{Conclusions}

This study analyzed the spatial spread and deposition onto the floor in an empty chamber and onto surfaces in a simplified hospital room of $S$. aureus bioaerosol as a validation dataset for comparison with aqueous $\mathrm{Li}$ and $\mathrm{Na}$ aerosols. Nebulization methods typical of bioaersol production were found to be applicable to aerosolization ofinorganic solutions. Metal concentrations were analyzed using flame atomic absorption spectroscopy, and the results indicated that the Li tracer correlates with the equivalent concentration and distribution of S. aureus bioaerosols; $\mathrm{Na}$, however, did not. Results 
showed that the inorganic technique is sensitive to spatial distribution but overpredicts bioburden in areas where air speed was thought to be high. Na sample distribution was found to exhibit high levels of homogeneity and hence are not a good pattern representation. On the other hand, Li aerosols were reliable in predicting the deposition behavior of small S. aureus bioaerosols in these environments.

The FAAS approach is robust to outliers, whereby fewer experimental replications were required to obtain the same spatial deposition patterns as the equivalent $S$. aureus spread. Additionally, since samples are non-toxic and do not degrade, this technique could be used as a viable method for in-situ hospital room testing during outbreak incidents or to inform risk assessments and hygiene strategies.

Acknowledgments: This work was carried out as part of a PhD studentship supported by Arup the UK Engineering and Physical Sciences Research Council (EPSRC) under the grant: Integrated hospital ward design for a safe and sustainable patient environment EP/G029768/1. The authors would like to thank Louise Fletcher and Sheena Bennett for their assistance with the experimental work. Experimental data can be found at: https:// doi.org/10.5518/291.

Author Contributions: M.-F.K., M.A.C.-V., P.A.S. and C.J.N. conceived and designed the experiments; M.-F.K. performed the experiments and analyzed the data; M.-F.K. and A.M.V. conducted spectroscopy analysis; M.-F.K., M.A.C.-V., A.M.V. and C.J.N. wrote the paper.

Conflicts of Interest: The authors declare no conflict of interest. The founding sponsors had no role in the design of the study; in the collection, analyses, or interpretation of data; in the writing of the manuscript, or in the decision to publish the results.

\section{References}

1. Graves, N. Economics and preventing hospital-acquired infection. Emerg. Infect. Dis. 2004, 10, 561-566. [CrossRef] [PubMed]

2. McBryde, E.S.; Bradley, L.C.; Whitby, M.; McElwain, D.L.S. An investigation of contact transmission of methicillin-resistant Staphylococcus aureus. J. Hosp. Infect. 2004, 58, 104-108. [CrossRef] [PubMed]

3. Smith, S.J.; Young, V.; Robertson, C.; Dancer, S.J. Where do hands go? An audit of sequential hand-touch events on a hospital ward. J. Hosp. Infect. 2012, 80, 206-211. [CrossRef] [PubMed]

4. Allegranzi, B.; Pittet, D. Role of hand hygiene in healthcare-associated infection prevention. J. Hosp. Infect. 2009, 73, 305-315. [CrossRef] [PubMed]

5. Tang, J.W.; Li, Y.; Eames, I.; Chan, P.K.S.; Ridgway, G.L. Factors involved in the aerosol transmission of infection and control of ventilation in healthcare premises. J. Hosp. Infect. 2006, 64, 100-114. [CrossRef] [PubMed]

6. Eames, I.; Shoaib, D.; Klettner, C.A.; Taban, V. Movement of airborne contaminants in a hospital isolation room. J. R. Soc. Interface 2009, 6, S757-S766. [CrossRef] [PubMed]

7. Bacaër, N.; Ouifki, R.; Pretorius, C.; Wood, R.; Williams, B. Modeling the joint epidemics of TB and HIV in a South African township. J. Math. Biol. 2008, 57, 557-593. [CrossRef] [PubMed]

8. Escombe, A.R.; Huaroto, L.; Ticona, E.; Burgos, M.; Sanchez, I.; Carrasco, L.; Farfán, E.; Flores, F.; Moore, D.A.J. Tuberculosis transmission risk and infection control in a hospital emergency department in Lima, Peru. Int. J. Tuberc. Lung Dis. 2010, 14, 1120-1126. [PubMed]

9. Anderson, R.E.; Young, V.; Stewart, M.; Robertson, C.; Dancer, S.J. Cleanliness audit of clinical surfaces and equipment: Who cleans what? J. Hosp. Infect. 2011, 78, 178-181. [CrossRef] [PubMed]

10. Dancer, S.J.; White, L.F.; Lamb, J.; Girvan, E.K.; Robertson, C. Measuring the effect of enhanced cleaning in a UK hospital: A prospective cross-over study. BMC Med. 2009, 7, 28. [CrossRef] [PubMed]

11. Khan, A.S.; Dancer, S.J.; Humphreys, H. Priorities in the prevention and control of multidrug-resistant Enterobacteriaceae in hospitals. J. Hosp. Infect. 2012, 82, 85-93. [CrossRef] [PubMed]

12. Zarpellon, M.N.; Gales, A.C.; Sasaki, A.L.; Selhorst, G.J.; Menegucci, T.C.; Cardoso, C.L.; Garcia, L.B.; Tognim, M.C.B. Survival of vancomycin-intermediate Staphylococcus aureus on hospital surfaces. J. Hosp. Infect. 2015, 90, 347-350. [CrossRef] [PubMed]

13. Boyce, J.M.; Havill, N.L.; Otter, J.A.; McDonald, L.C.; Adams, N.M.T.; Cooper, T.; Thompson, A.; Wiggs, L.; Killgore, G.; Tauman, A.; et al. Impact of hydrogen peroxide vapor room decontamination on Clostridium difficile environmental contamination and transmission in a healthcare setting. Infect. Control Hosp. Epidemiol. 2008, 29, 723-729. [CrossRef] [PubMed] 
14. Noakes, C.J.; Sleigh, P.A. Mathematical models for assessing the role of airflow on the risk of airborne infection in hospital wards. J. R. Soc. Interface 2009, 6, S791-S800. [CrossRef] [PubMed]

15. Dancer, S.J. Mopping up hospital infection. J. Hosp. Infect. 1999, 43, 85-100. [CrossRef] [PubMed]

16. Kiss, I.Z.; Green, D.M.; Kao, R.R. The effect of contact heterogeneity and multiple routes of transmission on final epidemic size. Math. Biosci. 2006, 203, 124-136. [CrossRef] [PubMed]

17. Pittet, D.; Allegranzi, B.; Sax, H.; Dharan, S.; Pessoa-Silva, C.L.; Donaldson, L.; Boyce, J.M. Evidence-based model for hand transmission during patient care and the role of improved practices. Lancet Infect. Dis. 2006, 6, 641-652. [CrossRef]

18. King, M.F.; Noakes, C.J.; Sleigh, P.A.; Bale, S.; Waters, L. Relationship between healthcare worker surface contacts, care type and hand hygiene: An observational study in a single-bed hospital ward. J. Hosp. Infect. 2016, 94, 48-51. [CrossRef] [PubMed]

19. Ramos, T.; Dedesko, S.; Siegel, J.A.; Gilbert, J.A.; Stephens, B. Spatial and temporal variations in indoor environmental conditions, human occupancy, and operational characteristics in a new hospital building. PLoS ONE 2015, 10, 1-24. [CrossRef] [PubMed]

20. Beggs, C.B.; Noakes, C.J.; Sleigh, P.A.; Fletcher, L.A.; Siddiqi, K. The transmission of tuberculosis in confined spaces: An analytical review of alternative epidemiological models. Int. J. Tuberc. Lung Dis. 2003, 7, 1015-1026. [PubMed]

21. Escombe, A.R.; Moore, D.A.J.; Gilman, R.H.; Navincopa, M.; Ticona, E.; Mitchell, B.; Noakes, C.; Martínez, C.; Sheen, P.; Ramirez, R.; et al. Upper-room ultraviolet light and negative air ionization to prevent tuberculosis transmission. PLoS Med. 2009, 6, e1000043. [CrossRef] [PubMed]

22. Xie, X. Evaporation and Movement of Respiratory Droplets in Indoor Environments. Ph.D. Thesis, The University of Hong Kong, Hong Kong, China, 2008.

23. Liu, L.; Wei, J.; Li, Y.; Ooi, A. Evaporation and dispersion of respiratory droplets from coughing. Indoor Air 2017, 27, 179-190. [CrossRef] [PubMed]

24. Hathway, E.A.; Noakes, C.J.; Sleigh, P.A.; Fletcher, L.A. CFD simulation of airborne pathogen transport due to human activities. Build. Environ. 2011, 46, 2500-2511. [CrossRef]

25. King, M.F.; Noakes, C.J.; Sleigh, P.A.; Camargo-Valero, M.A. Bioaerosol deposition in single and two-bed hospital rooms: A numerical and experimental study. Build. Environ. 2013, 59, 436-447. [CrossRef]

26. Wong, L.T.; Chan, W.Y.; Mui, K.W.; Lai, A.C.K. An Experimental and Numerical Study on Deposition of Bioaerosols in a Scaled Chamber. Aerosol Sci. Technol. 2010, 44, 117-128. [CrossRef]

27. Sinclair, R.G.; Rose, J.B.; Hashsham, S.A.; Gerba, C.P.; Haase, C.N. Criteria for selection of surrogates used to study the sate and control of pathogens in the environment. Appl. Environ. Microbiol. 2012, 78, 1969-1977. [CrossRef] [PubMed]

28. Hunter, M.; Westgate, M.; Barton, P.; Calhoun, A.; Pierson, J.; Tulloch, A.; Beger, M.; Branquinho, C.; Caro, T.; Gross, J.; et al. Two roles for ecological surrogacy: Indicator surrogates and management surrogates. Ecol. Indic. 2016, 63, 121-125. [CrossRef]

29. Mulvey, D.; Redding, P.; Robertson, C.; Woodall, C.; Kingsmore, P.; Bedwell, D.; Dancer, S.J. Finding a benchmark for monitoring hospital cleanliness. J. Hosp. Infect. 2011, 77, 25-30. [CrossRef] [PubMed]

30. Roberts, K.A. The Use of UV to Disinfect Airborne Pathogens. Ph.D. Thesis, University of Leeds, Leeds, UK, 2008.

31. Bishop, A.H.; Stapleton, H.L. Aerosol and surface deposition characteristics of two surrogates for Bacillus anthracis spores. Appl. Environ. Microbiol. 2016, 82, 6682-6690. [CrossRef] [PubMed]

32. Ramos, T.; Stephens, B. Tools to improve built environment data collection for indoor microbial ecology investigations. Build. Environ. 2014, 81, 243-257. [CrossRef]

33. Jung, J.H.; Lee, J.E. Variation in the fluorescence intensity of thermally-exposed bacterial bioaerosols. J. Aerosol Sci. 2013, 65, 101-110. [CrossRef]

34. Hathway, E.A.; Noakes, C.J.; Fletcher, L.A.; Sleigh, P.A.; Clifton, I.; Elliott, M.W. The Role of Nursing Activities on the Bioaerosol Production in Hospital Wards. Indoor Built Environ. 2013, 22, 410-421. [CrossRef]

35. Lewis, T.; Griffith, C.; Gallo, M.; Weinbren, M. A modified ATP benchmark for evaluating the cleaning of some hospital environmental surfaces. J. Hosp. Infect. 2008, 69, 156-163. [CrossRef] [PubMed]

36. Sze To, G.N.; Wan, M.P.; Chao, C.Y.H.; Wei, F.; Yu, S.C.T.; Kwan, J.K.C. A methodology for estimating airborne virus exposures in indoor environments using the spatial distribution of expiratory aerosols and virus viability characteristics. Indoor Air 2008, 18, 425-438. [CrossRef] [PubMed] 
37. Johnson, D.L.; Lynch, R.A. An efficient analytical method for particle counting in evaluating airborne infectious isolation containment using fluorescent microspheres. J. Occup. Environ. Hyg. 2008, 5, 271-277. [CrossRef] [PubMed]

38. Rydock, J.P. A Simple Method for Tracer Containment Testing of Hospital Isolation Rooms. Appl. Occup. Environ. Hyg. 2002, 17, 486-490. [CrossRef] [PubMed]

39. Cheong, K.W.D.; Phua, S.Y. Development of ventilation design strategy for effective removal of pollutant in the isolation room of a hospital. Build. Environ. 2006, 41, 1161-1170. [CrossRef]

40. Tang, J.W.; Noakes, C.J.; Nielsen, P.V.; Eames, I.; Nicolle, A.; Li, Y.; Settles, G.S. Observing and quantifying airflows in the infection control of aerosol- and airborne-transmitted diseases: An overview of approaches. J. Hosp. Infect. 2011, 77, 213-222. [CrossRef] [PubMed]

41. Qian, H.; Li, Y.; Nielsen, P.V.; Huang, X. Spatial distribution of infection risk of SARS transmission in a hospital ward. Build. Environ. 2009, 44, 1651-1658. [CrossRef]

42. Fabian, P.; McDevitt, J.J.; DeHaan, W.H.; Fung, R.O.P.; Cowling, B.J.; Chan, K.H.; Leung, G.M.; Milton, D.K. Influenza virus in human exhaled breath: An observational study. PLoS ONE 2008, 3, e2691. [CrossRef] [PubMed]

43. Olmedo, I.; Nielsen, P.V.; Ruiz de Adana, M.; Jensen, R.L.; Grzelecki, P. Distribution of exhaled contaminants and personal exposure in a room using three different air distribution strategies. Indoor Air 2012, 22, 64-76. [CrossRef] [PubMed]

44. Bjørn, E.; Nielsen, P.V. Dispersal of exhaled air and personal exposure in displacement ventilated rooms. Indoor Air 2002, 12, 147-164. [CrossRef] [PubMed]

45. Gilkeson, C.A.; Camargo-Valero, M.A.; Pickin, L.E.; Noakes, C.J. Measurement of ventilation and airborne infection risk in large naturally ventilated hospital wards. Build. Environ. 2013, 65, 35-48. [CrossRef]

46. Sze To, G.N.; Chao, C.Y.H. Review and comparison between the Wells-Riley and dose-response approaches to risk assessment of infectious respiratory diseases. Indoor Air 2010, 20, 2-16. [CrossRef] [PubMed]

47. Zoon, W.A.C.; Loomans, M.G.L.C.; Hensen, J.L.M. Testing the effectiveness of operating room ventilation with regard to removal of airborne bacteria. Build. Environ. 2011, 46, 2570-2577. [CrossRef]

48. Zhu, S.; Kato, S.; Yang, J.H. Study on transport characteristics of saliva droplets produced by coughing in a calm indoor environment. Build. Environ. 2006, 41, 1691-1702. [CrossRef]

49. Best, E.L.; Parnell, P.; Wilcox, M.H. Microbiological comparison of hand-drying methods: The potential for contamination of the environment, user, and bystander. J. Hosp. Infect. 2014, 88, 199-206. [CrossRef] [PubMed]

50. McDonagh, A.; Sextro, R.G.; Byrne, M.A. Mass transport of deposited particles by surface-to-surface contact. J. Hazard. Mater. 2012, 227, 370-377. [CrossRef] [PubMed]

51. Aliasgharpour, M.; Hagani, H. Evaluation of lithium determination in three analyzers: Flame emission, flame atomic absorption spectroscopy and ion selective electrode. N. Am. J. Med. Sci. 2009, 1, $244-246$. [PubMed]

52. Julian, T.R.; Canales, R.A.; Leckie, J.O.; Boehm, A.B. A model of exposure to rotavirus from nondietary ingestion iterated by simulated intermittent contacts. Risk Anal. 2009, 29, 617-632. [CrossRef] [PubMed]

53. Sickbert-Bennett, E.E.; Weber, D.J.; Gergen-Teague, M.F.; Sobsey, M.D.; Samsa, G.P.; Rutala, W.A. Comparative efficacy of hand hygiene agents in the reduction of bacteria and viruses. Am. J. Infect. Control 2005, 33, 67-77. [CrossRef] [PubMed]

54. Tung-Thompson, G.; Libera, D.A.; Koch, K.L.; De Los Reyes, F.L.; Jaykus, L.A. Aerosolization of a human norovirus surrogate, bacteriophage MS2, during simulated vomiting. PLoS ONE 2015, 10, e0134277. [CrossRef] [PubMed]

55. Seo, E.Y.; Ahn, T.S.; Zo, Y.G. Agreement, precision, and accuracy of epifluorescence microscopy methods for enumeration of total bacterial numbers. Appl. Environ. Microbiol. 2010, 76, 1981-1991. [CrossRef] [PubMed]

56. Sattar, S.A.; Springthorpe, S.; Mani, S.; Gallant, M.; Nair, R.C.; Scott, E.; Kain, J. Transfer of bacteria from fabrics to hands and other fabrics: Development and application of a quantitative method using Staphylococcus aureus as a model. J. Appl. Microbiol. 2001, 90, 962-970. [CrossRef] [PubMed]

57. Qian, H.; Li, Y.; Nielsen, P.V.; Hyldgaard, C.E. Dispersion of exhalation pollutants in a two-bed hospital ward with a downward ventilation system. Build. Environ. 2008, 43, 344-354. [CrossRef] 
58. Gilkeson, C.A.; Noakes, C.J.; Sleigh, P.A.; Khan, M.A.I. Simulating Pathogen Transport within a Naturally Ventilated Hospital Ward. In Proceedings of the International Conference on Computational Fluid Dynamics, Paris, France, 27-29 July 2011.

59. Tang, J.W.; Liebner, T.J.; Craven, B.A.; Settles, G.S. A schlieren optical study of the human cough with and without wearing masks for aerosol infection control. J. R. Soc. Interface 2009, 6, S727-S736. [CrossRef] [PubMed]

60. Heating and Ventilation of Health Sector Buildings (HTM 03-01); Department of Health: London, UK, 2007.

61. Bland, J.M.; Altman, D.G. Statistical methods for assessing agreement between two methods of clinical measurement. Int. J. Nurs. Stud. 2010, 47, 931-936. [CrossRef]

62. Dancer, S.J.; Anderson, R.; Young, V.; Stewart, M. P11.05 Cleanliness audit of clinical surfaces and equipment: Who cleans what? J. Hosp. Infect. 2010, 76, S34. [CrossRef]

63. Rountree, P.M. The Effect of Desiccation on the Viability of Staphylococcus Aureus. J. Hyg. 1963, 61, $265-272$. [CrossRef] [PubMed]

64. Beauchêne, C.; Laudinet, N.; Choukri, F.; Rousset, J.L.; Benhamadouche, S.; Larbre, J.; Chaouat, M.; Benbunan, M.; Mimoun, M.; Lajonchère, J.P.; et al. Accumulation and transport of microbial-size particles in a pressure protected model burn unit: CFD simulations and experimental evidence. BMC Infect. Dis. 2011, 11, 58. [CrossRef] [PubMed]

65. Noakes, C.J.; Fletcher, L.A.; Sleigh, P.A.; Booth, W.B.; Beato-Arribas, B.; Tomlinson, N. Comparison of tracer techniques for evaluating the behaviour of bioaerosols in hospital isolation rooms. In Proceedings of the Healthy Buildings, Kuala Lumpur, Malaysia, 13-17 September 2009.

66. Dancer, S.J.; Crawford, A. Keeping hospital MRSA out of a district general. J. Hosp. Infect. 1999, 43, $19-27$. [CrossRef]

67. Otter, J.A.; Yezli, S.; French, G.L. The role played by contaminated surfaces in the transmission of nosocomial pathogens. Infect. Control Hosp. Epidemiol. 2011, 32, 687-699. [CrossRef] [PubMed]

(C) 2017 by the authors. Licensee MDPI, Basel, Switzerland. This article is an open access article distributed under the terms and conditions of the Creative Commons Attribution (CC BY) license (http:/ / creativecommons.org/licenses/by/4.0/). 